\title{
Production of Cellulase and Xylanase by Aspergillus terreus KJ829487 Using Cassava Peels as Subtrates
}

\author{
Afolake Atinuke Olanbiwoninu ${ }^{1 *}$, Sunday Ayodele Odunfa ${ }^{2}$ \\ ${ }^{1}$ Department of Biological Sciences, Faculty of Natural Sciences, Ajayi Crowther University, Oyo, Nigeria \\ ${ }^{2}$ Department of Microbiology, Faculty of Sciences, University of Ibadan, Ibadan, Nigeria \\ Email: *flakyolanbiwonninu@yahoo.com
}

Received 18 April 2016; accepted 19 June 2016; published 22 June 2016

Copyright (C) 2016 by authors and Scientific Research Publishing Inc.

This work is licensed under the Creative Commons Attribution International License (CC BY). http://creativecommons.org/licenses/by/4.0/

c) (7) Open Access

\begin{abstract}
Cassava (Manihot esculenta, Crantz) is one of the most important food plants in West Africa. Its peels are made up of cellulose, hemicellulose and lignin. This lignocellulolytic biomass can be converted using microbial enzymes to fermentable sugars which have wide range of biotechnological relevance in many fermentation processes. The aim of this study is to screen filamentous fungi from decaying cassava peels that are good producers of xylanases and cellulases. Decaying parts of cassava peels were obtained and brought to the laboratory for further work. Fungi were isolated, identified and screened for cellulase and xylanase production. Isolate with highest frequency of occurrence and enzyme production was identified using phenotypic and molecular method. Optimisation of growth conditions for enzymes production was monitored using the DNSA method, also saccharification of cassava peel were carried out using the enzymes obtained from the isolate. Aspergillus terreus $\mathrm{KJ} 829487$ was the predominant fungus. It produces cellulases and xylanases optimally at $40^{\circ} \mathrm{C}, \mathrm{pH} 6$ and 8, utilising carboxymethylcellulose (CMC) or xylose and yeast extracts as its carbon and nitrogen sources respectively. Saccharification of the peels yielded $584 \mathrm{mg} / \mathrm{L}$ glucose, $78 \mathrm{mg} / \mathrm{L}$ xylose and $66 \mathrm{mg} / \mathrm{L}$ rhamnose. Aspergillus terreus KJ829487 obtained from cassava peels have the ability to produce high concentration cellulases and xylanases which effectively hydrolysed the lignocelluloses' biomass to fermentable sugars.
\end{abstract}

\section{Keywords}

Cassava Peels, Aspergillus terreus, Cellulase, Xylanase, Lignocelluloses, Fermentable Sugars

\footnotetext{
*Corresponding author.
} 


\section{Introduction}

Cassava (Manihot esculenta, Crantz) peels are the main by-product from processing tuberous roots of cassava for human consumption. The peel is $1-4 \mathrm{~mm}$ thick and may account for $10 \%-12 \%$ of the total dry matter of the root [1]. Cassava peels are lignocellulolytic biomass which is considered as an agricultural residue because it is discarded during processing. The degradation of this complex structure requires a complete enzymatic system.

Cellulose is a linear polysaccharide composed of $\beta$-1, 4-linked glucose molecules. Efficient hydrolysis of cellulose requires the action of a complex of cellulolytic enzymes that work synergistically: exo-1, $4-\beta$-D-glucanases, endo-1-4- $\beta$-D-glucanases and 1,4- $\beta$-Dglucanases [2]. The production of cellulases by fungi and bacteria is widely disseminated in nature. Among fungi, the genera Trichoderma, Aspergillus, Penicillium, Humicola are described as cellulase producers, Aspergillus spp. is the major agents of decomposition and decay, therefore they produce a broad range of enzymes, including cellulases and xylanases and these reports have been well documented [3]-[8]. At present, there is an increasing demand for these enzymes, especially for bioconversion of agricultural resources and ethanol production because cellulase helps in hydrolyzing cellulose to produce glucose [9].

Hemicellulose is a linear and branched heterogeneous polymer typically made up of five different sugarsL-arabinose, D-galactose, D-glucose, D-mannose, and D-xylose [10]. Xylanases are responsible for the hydrolysis of xylan and subsequently releasing xylo-oligosaccharides [11]. The hydrolysed products in the form of soluble sugars have extensive range of biotechnological relevance in many fermentation processes and functional food industry [12]. Literature review shows that, a large variety of microorganisms, including bacteria, yeast and filamentous fungi have been reported to produce xylanase [13]. From an industrial perspective, fungi are interesting due to higher extracellular release of xylanases, in addition to production of several auxiliary enzymes that are necessary for debranching of the substituted xylans [14].

Lignin represents about $15 \%$ - $25 \%$ of lignocellulosic biomass and is a large cross-linked macromolecule composed of three monomers: p-coumaryl alcohol, coniferyl alcohol and sinapyl alcohol [15]. The enzymes responsible for lignin degradation are mainly lignin-peroxidase (LiP), manganese peroxidase (MnP), laccases and hydrogen peroxide-producing enzymes. A wide variety of microorganisms, including fungi, actinomycetes and bacteria, have been implicated in lignin biodegradation. Among them, white rot fungi have received extensive attention due to their powerful extracellular lignin-degrading enzymatic systems [16]. Other groups of fungi have also been reported as producers of lignolytic enzymes [17].

Filamentous fungi are good examples of microorganisms that produce cellulase and xylanase on industrial scale and they can easily be obtained from lignocellulolytic biomass. The aim of this study is to screen filamentous fungi from decaying lignocellulolytic agricultural waste products that are good producers of xylanases and cellulases.

\section{Materials and Methods}

\subsection{Collection of Samples}

Decaying parts of cassava peels were collected from the dumping site of a cassava processing site in Old-Ife Road, Ibadan, Oyo State, Nigeria.

\subsection{Strain Isolation and Identification}

The filamentous fungi were isolated from the decaying parts of cassava peels and the technique of [17] James and Natalie, 2001 was used for identification using Lactophenol blue stain. The identification was done by placing a drop of the stain on clean slide, using a mounting needle; small portion of the mycelium from the fungal cultures was removed and placed in a drop of lactophenol. The mycelium was spread on the slide and gently covered with a cover slip applying small pressure so as to eliminate air bubbles. The slide was mounted in an optical microscope (Olympus $\mathrm{CH}$ ) and observed using 10 and 40× lenses respectively. The species obtained were identified in accordance to [18].

\subsection{Selection of Isolate}

Aspergillus terreus was the most predominant fungus present. Therefore, it was selected for further studies. 


\subsection{Enzymes Assay Substrate}

Xylan powder and carboxymethylcellulose (CMC) powder was used for assay of xylanase and carboxymethylcellulase enzyme. The purpose of the assay is to check the purity of these enzymes. The powders were obtained from Sigma-Aldrich Incorporation, Germany.

\subsection{Screening of Isolates for Enzyme Production}

Each fungal isolates obtained were screened for cellulase and xylanase production. Chemically defined media composed of $\mathrm{KH}_{2} \mathrm{PO}_{4}(1 \mathrm{~g} / \mathrm{L}), \mathrm{MgSO}_{4} \cdot 7 \mathrm{H}_{2} \mathrm{O}(0.5 \mathrm{~g} / \mathrm{L})$, yeast extract $(1 \mathrm{~g} / \mathrm{L}), \mathrm{CaCl}_{2} \cdot 2 \mathrm{H}_{2} \mathrm{O}(0.14 \mathrm{~g} / \mathrm{L})$, $\mathrm{CMC}$ or Xylan $(10 \mathrm{~g} / \mathrm{L})$ and thiamine $(0.0025 \mathrm{~g} / \mathrm{L})$ were prepared [19]. The media were dispensed into screw capped bottles and sterilized at $121^{\circ} \mathrm{C}$ for fifteen minutes in an autoclave. After cooling, the medium was inoculated with one disk of agar of the fungal mycelium obtained by using a sterile cork borer $(9 \mathrm{~mm})$. Uninoculated medium served as control. After growth had been allowed to proceed for the required length of time at the required temperature, the cultures were centrifuged using refrigerated centrifuge (IEC, Centra, MP4R Model) at $3000 \mathrm{rpm}$ for 15 minutes. Culture supernatant $(1 \mathrm{ml})$ was added to $9 \mathrm{ml}$ of the substrate containing $0.55 \% \mathrm{w} / \mathrm{v}$ of CMC (carboxymethyl cellulose) in $0.55 \mathrm{M}$ acetate buffer $\mathrm{pH} 5.5$ for cellulase and $1.0 \% \mathrm{w} / \mathrm{v}$ of xylan in $0.2 \mathrm{M}$ acetate buffer $\mathrm{pH} 4.5$ for xylanase (hemicellulase) assay. Subsequently, they were incubated at $45^{\circ} \mathrm{C}$ for 1 hour. Each reaction was halted by adding a drop of $5 \mathrm{M} \mathrm{NaOH}$. To estimate the amount of reducing sugars released, dinitrosalicyclic acid (DNSA) reagent $(1 \mathrm{ml})$ was added to $1 \mathrm{ml}$ of the filtrate-CMC/xylan reaction mixture and boiled at $100^{\circ} \mathrm{C}$ for 10 minutes in a water bath [20]. After cooling, the absorbance was determined at $540 \mathrm{~nm}$ using a Jenway 6405/VIS spectrophotometer. The absorbance of standard aqueous solutions of D-glucose and xylose of various concentrations $(0-10 \mathrm{mgml})$ at $540 \mathrm{~nm}$ was determined and used to construct a graph of percentage absorbance as related to $\mathrm{mg}$ of glucose or xylose per $\mathrm{ml}$. The amount of reducing sugar produced by 1 $\mathrm{ml}$ of fungi filtrate from the CMC assay medium and xylan assay medium was calculated from this graph. Cellulolytic and hemicellulolytic activities of the filtrates were then expressed in terms of the amount of total reducing sugars (RS) per ml.

\subsection{Molecular Identification of Fungus}

The internal transcribed spacer (ITS) sequence of the fungus was amplified by polymerase chain reaction (PCR) with the primers ITS1 (5-CTTGGTCATTTAGAGGAAGTAA-3 ${ }^{1}$ ) and ITS2 (5-TCCTCCGCTTATTGATATGC$3^{1}$ ). The amplification was performed using a PCR cycler under the following cycling parameters: $94^{\circ} \mathrm{C}$ for 4 minutes, followed by 37 cycles of 30 s at $92^{\circ} \mathrm{C}$, 30s at $55^{\circ} \mathrm{C}$ and $1 \mathrm{~min}$ at $68^{\circ} \mathrm{C}$ with final extension of $68^{\circ} \mathrm{C}$ for 1 minute. Sequencing of the purified PCR amplicon was done using ABI Bigdye 3.1 cycle sequencing kit (Applied Biosystems, California, USA) on ABI 3730XL and the nucleotide sequence determined by automated sequencer by Laragen Inc., Culver City California. The nucleotide sequences of ITS1/ITS2 of the isolate was aligned and analyzed by using Basic Local Alignment Search Tool (BLAST) program available at http://www.ncbi.nlm.nih.gov [21].

\subsection{Enzyme Production and Extracts}

Isolate was grown in a $250 \mathrm{ml}$ glass bottle containing $10 \mathrm{~g}$ of substrate (cassava peel) and yeast extract as a nitrogen source. Moisture content was adjusted to $20 \%-40 \%(\mathrm{w} / \mathrm{w})$ by adding distilled water and sterilized at $121^{\circ} \mathrm{C}$ for 15 minutes. The bottle was inoculated with $5 \mathrm{mls}$ of the fungi grown for 7 days $\left(1 \times 10^{6}\right.$ spores/ml) and incubated at $30^{\circ} \mathrm{C}$ for $5-7$ days. Experiment was carried out in triplicates.

At the end of the incubation period, $0.1 \mathrm{M}$ citrate buffer with $\mathrm{pH} 4.8$ was added to give a total of $50 \mathrm{ml} / \mathrm{flask}$. The flasks were shaken using an orbital shaker at $150 \mathrm{rpm}$ for $1 \mathrm{hr}$ then filtered to obtain clear filtrate for determining enzyme activity.

\subsection{Optimization of Cultural Conditions for Enzyme Production}

The isolate was grown in chemically defined media composed of $\mathrm{KH}_{2} \mathrm{PO}_{4}(1 \mathrm{~g} / \mathrm{L}), \mathrm{MgSO}_{4} \cdot 7 \mathrm{H}_{2} \mathrm{O}(0.5 \mathrm{~g} / \mathrm{L})$, yeast extract $(1 \mathrm{~g} / \mathrm{L}), \mathrm{CaCl}_{2} \cdot 2 \mathrm{H}_{2} \mathrm{O}(0.14 \mathrm{~g} / \mathrm{L})$, CMC/xylan $(10 \mathrm{~g} / \mathrm{L})$ and thiamine $(0.0025 \mathrm{~g} / \mathrm{L})$ according to [22]. 


\subsection{Effect of Temperature on Cellulase and Xylanase Activity}

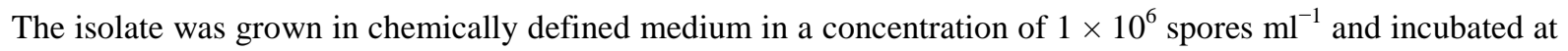
temperatures of $27^{\circ} \mathrm{C}, 40^{\circ} \mathrm{C}, 50^{\circ} \mathrm{C}, 60^{\circ} \mathrm{C}$ and $70^{\circ} \mathrm{C}$ for 5 days. All were done in triplicates. After incubation, the content of the flask was centrifuged and the cell free supernatant was assayed for cellulose and xylanase synthesis using the DNSA method to estimate the amount of reducing sugars released.

\subsection{Effect of $\mathrm{pH}$ on Cellulase and Xylanase Activity}

The isolate was grown in chemically defined medium with a concentration of $1 \times 10^{6}$ spores $\mathrm{ml}^{-1}$, adjusting the $\mathrm{pH}$ from 6 to 10 and incubated for 5 days. After incubation, the content of the flask was centrifuged and the cell free supernatant was assayed for cellulase and xylanase synthesis using the DNSA method to estimate the amount of reducing sugars released.

\subsection{Effect of Carbon Source on Cellulase and Xylanase Activity}

The isolate was grown in chemically defined medium with a concentration of $1 \times 10^{6}$ spores' $^{\prime-1}$. The carbon source was substituted using glucose, xylose, raffinose, carboxymethylcellulose, mannitol and lactose. Incubation was done at the optimum $\mathrm{pH}$ and temperature for 5 days. After incubation, the content of the flask were centrifuged and the cell free supernatant was analyzed for cellulose and xylanase as analyzed for cellulose and xylanase synthesis using the DNSA method to estimate the amount of reducing sugars released.

\subsection{Effect on Nitrogen Source on Cellulase and Xylanase Activity}


gen source was substituted using peptone, urea, $\left(\mathrm{NH}_{4}\right)_{2} \mathrm{SO}_{4}, \mathrm{NaNO}_{3}$ and yeast extract. Incubation was done at the optimum temperature, $\mathrm{pH}$ and carbon source and incubated accordingly for 5 days. After incubation, the content of the flask was centrifuged and the cell free supernatant was assayed for cellulase and xylanase synthesis using the DNSA method to estimate the amount of reducing sugars released.

\subsection{Enzyme Assay}

The cellulase and xylanase was assayed by incubating $1 \mathrm{ml}$ of crude enzyme with $9 \mathrm{ml}$ of $0.55 \mathrm{M}$ sodium acetate buffer $\mathrm{pH} 5.5$ containing $0.55 \% \mathrm{w} / \mathrm{w}$ CMC and $0.2 \mathrm{M}$ acetate buffer $\mathrm{pH} 4.5$ containing $1.0 \% \mathrm{w} / \mathrm{v}$ xylan at $45^{\circ} \mathrm{C}$ for 1 hour. The amount of reducing sugars released was determined by the 3, 5-dinitrosalicyclic acid (DNS) method [20].

\subsection{Enzyme Activity}

This is determined based on one unit (u) of the enzyme activity i.e. the amount of enzyme required to release 1 unit of products (glucose or xylose) from cassava peels per minute under the assay conditions. In this study, the enzyme activities are expressed as units per gram of cassava peels (U/g).

\subsection{Alkali Pretreatment by $\mathrm{NaOH}$}

Twenty grammes of cassava peel was suspended in $80 \mathrm{mls}$ of $0.01 \mathrm{M}$ to $3 \mathrm{M}$ sodium hydroxide (NaOH), incubated at room temperature for $1 \mathrm{~h}$ in a $500 \mathrm{ml}$ beaker for cold treatment while for heat treatment the beakers were placed in an autoclave at temperature between $100^{\circ} \mathrm{C}$ and $135^{\circ} \mathrm{C}$ with exposure time varying from 15 min to 60 mins. The solid residues were collected and washed thoroughly with tap water until neutral $\mathrm{pH}$ was reached prior to enzymatic hydrolysis [23].

\subsection{Acid Pretreatment by $\mathrm{H}_{2} \mathrm{SO}_{4}$}

The $2 \%$ cassava peels was hydrolyzed with acid (sulphuric acid) of different concentrations ranging from 0.01 to $3 \mathrm{M}$. The hydrolysis conditions were performed at $121^{\circ} \mathrm{C}$ for $30 \mathrm{~min}$. The hydrolysates were separated by a centrifuge at $6500 \mathrm{rpm}$ for $10 \mathrm{~min}$. Each sample was neutralized by $1 \mathrm{M} \mathrm{NaOH}$ solution for analysis of reducing sugar with DNSA method. The acid concentration that gave a maximum reduce sugars was chosen. The selected 
acid concentration was applied to determine the optimum temperature for cassava peel hydrolysis. A temperature range used in this study was between $100^{\circ} \mathrm{C}$ and $135^{\circ} \mathrm{C}$ and hydrolysis time was from 15 to 60 min for heat treatment. Cold treatment was done by incubating suspended cassava peel in $0.01 \mathrm{M}$ to $3 \mathrm{M}$ sulphuric acid for 1h. The solid residues were collected and neutralized with $2 \mathrm{M} \mathrm{NaOH}$ and then washed thoroughly with tap water until neutral $\mathrm{pH}$ was reached prior to enzymatic hydrolysis [19].

\subsection{Saccharification of Pretreated Cassava Peel}

Following enzyme extraction, fungal cells were eliminated from the crude enzyme and one gram of pretreated cassava peel was saccharified with $5 \mathrm{ml}$ of crude enzymes $(3 \mathrm{U} / \mathrm{mL})$ of cellulase and xylanase respectively. The mixtures were incubated at $45^{\circ} \mathrm{C}$ for 3 days in an orbital shaker. The glucose and xylose yields were analyzed using gas chromatography (HP-6890 powered with HP ChemStation Rev, A 09.01 [1206] Software) with a BPX70 column and a flame ionization detector, detector temperature is $325^{\circ} \mathrm{C}$ the protocol of [24] was used.

\section{Results}

\subsection{Isolation of Fungi}

Thirteen fungal isolates were obtained from rotten cassava peels. Seven species of the genus Aspergillus were isolated; three species of Penicillium, two species of Rhizopus and Streptomyces and one Candida were also obtained. They were identified as Rhizopusoryzae, Aspergillus terreus, Penicillium expansum, Penicillium atrovenetum, Fusarium poae, Streptomyces nitrosporeus and Candida valida. A. terreus have the highest percentage occurrence and morphologically it was observed to have a black to dark brown colour; it has a velvety appearance, and it also has short aerial hyphae with black spots, the conidial head is columnar while the conidial globose is slightly ellipsoidal.

\subsection{Screening for Fungi Producing Cellulase and Xylanase}

The cellulase and xylanase production by fungal isolates are represented in Figure 1 Aspergillus terreus produced the highest concentration of cellulase and xylanase respectively $(2.7 \mathrm{U} / \mathrm{mL}$ and $3.4 \mathrm{U} / \mathrm{mL}$ ) while Candida valida produced the lowest concentration of $0.55 \mathrm{U} / \mathrm{ml}$ and $1.0 \mathrm{U} / \mathrm{mL}$ for both cellulase and xylanase.

\subsection{Molecular Identification of Isolates}

The nucleotide sequences were subjected to the basic alignment search tool (BLAST) (http//www.ncbi.nlm.nih.gov/blast/) where similarities and analysis was made from existing sequences in the database. The best cellulase or xylanase producers showed a 99\% identity with Aspergillus terreus and given ascension number KJ829487.

\subsection{Optimization of Conditions for Cellulase and Xylanase Production}

\subsubsection{Effect of $\mathrm{pH}$}

Five $\mathrm{pH}$ values ranging from 6 to 10 were picked for this study. The optimal $\mathrm{pH}$ for cellulase and xylanase production using cassava peels as the sole source of carbon was 6 and 8 producing $2.8 \mathrm{U} / \mathrm{mL}$ and $3.4 \mathrm{U} / \mathrm{mL}$ respectively (Figure 2).

\subsubsection{Effect of Temperature}

In this study, the production of cellulase and xylanase by Aspergillus terreus KJ829487 was determined after varying the temperature of incubation from $27^{\circ} \mathrm{C}$ to $70^{\circ} \mathrm{C}$. The greatest enzymatic production occurred at $40^{\circ} \mathrm{C}$ (Figure 3) for both cellulase and xylanase production $\left(2.8 \mathrm{U} / \mathrm{mL}\right.$ and $3.4 \mathrm{U} / \mathrm{mL}$ ), for the culture at $50^{\circ} \mathrm{C}$ to $70^{\circ} \mathrm{C}$, the enzymatic activities decline.

\subsubsection{Effect of Nitrogen Sources}

In this study, the supplementation of organic and inorganic nitrogen sources stimulated the cellulase and xylanase yield and activity, with the organic sources yielding higher concentration more than the inorganic ones. The organic nitrogen used for this study are peptone, urea and yeast extract and the inorganic nitrogen used are 


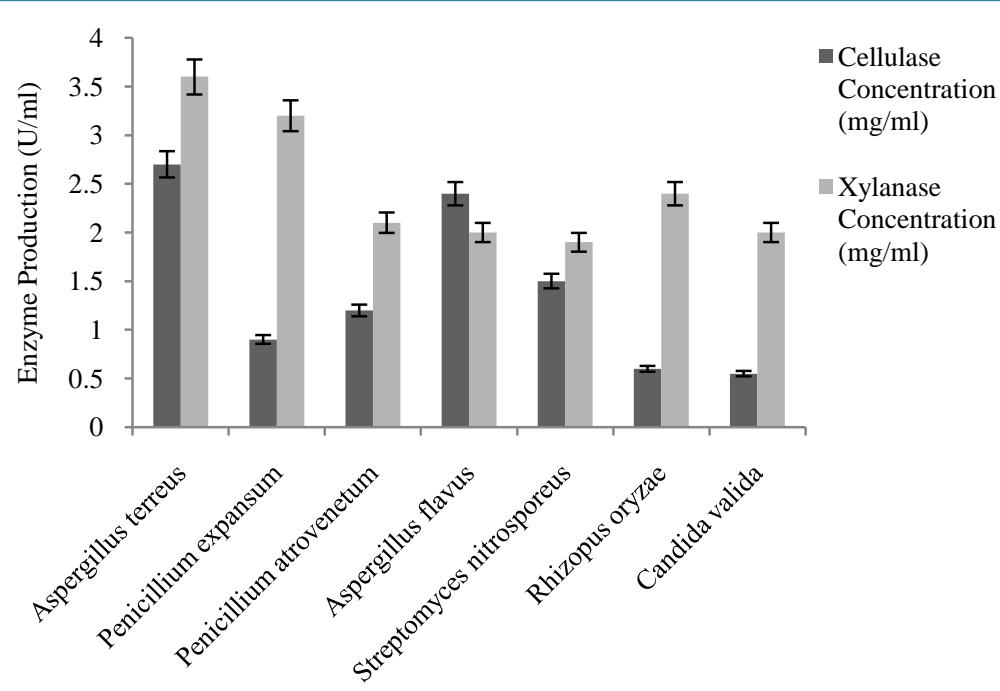

Figure 1. Cellulase and xylanase concentration of fungi isolated from rotten cassava peels in Ibadan.



Figure 2. Effect of $\mathrm{pH}$ on cellulase and xylanase production by Aspergillus terreus KJ829487.

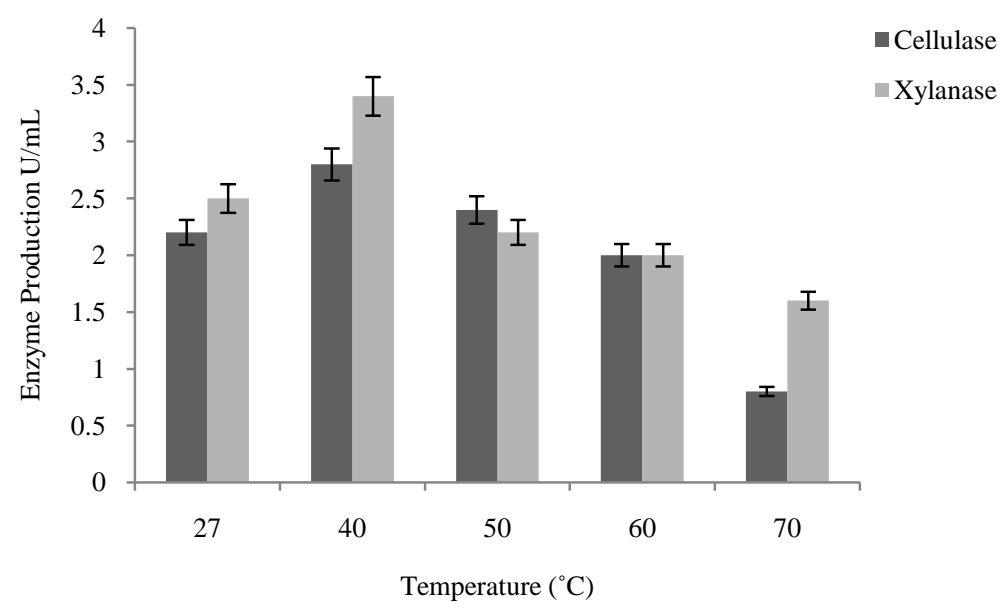

Figure 3. Effect of temperature on cellulase and xylanase production by Aspergillus terreus KJ829487. 
$\left(\mathrm{NH}_{4}\right)_{2} \mathrm{SO}_{4}$ and $\mathrm{NaNO}_{3}$. Yeast extract showed the highest cellulase and xylanase production $(2.8 \mathrm{U} / \mathrm{mL}, 3.8$ $\mathrm{U} / \mathrm{mL}$ ) and this is represented in the Figure 4.

\subsubsection{Effect of Carbon Sources}

The ability of A. terreus KJ829487 to utilize different carbon sources was monitored using various types of carbon (Figure 5) because the production of enzymes is related to the type and concentration of carbon source in the medium [25]. Addition of carboxymethyl cellulose (CMC) to the medium was most effective for cellulase production with $2.7 \mathrm{U} / \mathrm{mL}$ (Figure 5) concentration of cellulase produced, while xylose induces highest production of xylanase $(3.2 \mathrm{U} / \mathrm{mL})$.

\subsubsection{Saccharification of Pretreated Cassava Peels}

Enzymatic hydrolysis of pretreated cassava peels with A. terreus KJ829487 enzymes produced highest concentration of glucose $(584 \mathrm{mg} / \mathrm{L})$, xylose $(78 \mathrm{mg} / \mathrm{L})$ and rhamnose $(66 \mathrm{mg} / \mathrm{L})$ from dilute acid pretreated peels.

\section{Discussion}

The predominance of A. terreus in this study is in conformity with the work of [26] who stated that A. terreus

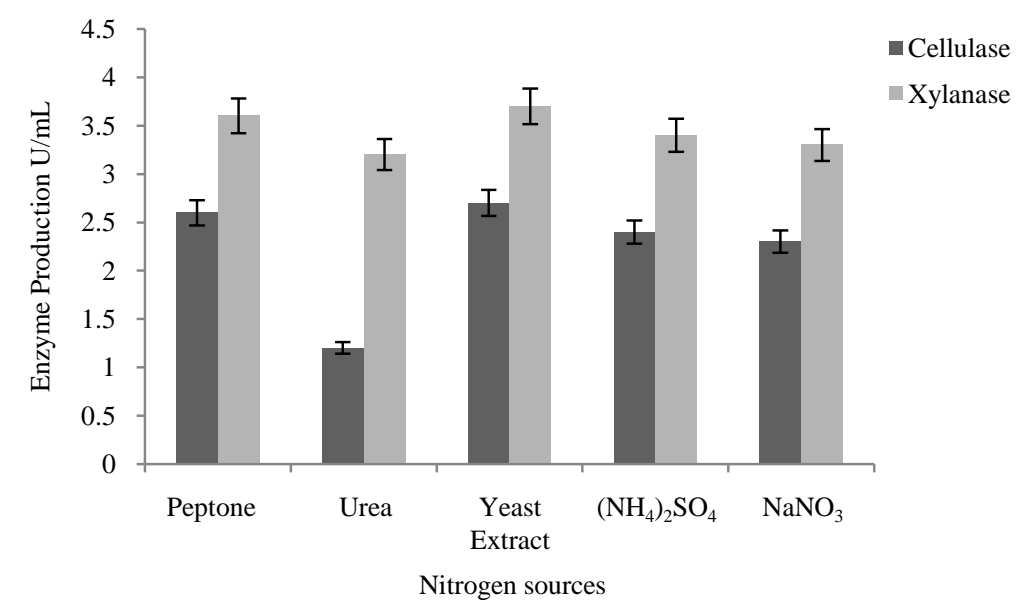

Figure 4. Effect of nitrogen sources on cellulase and xylanase production by Aspergillus terreus KJ829487.

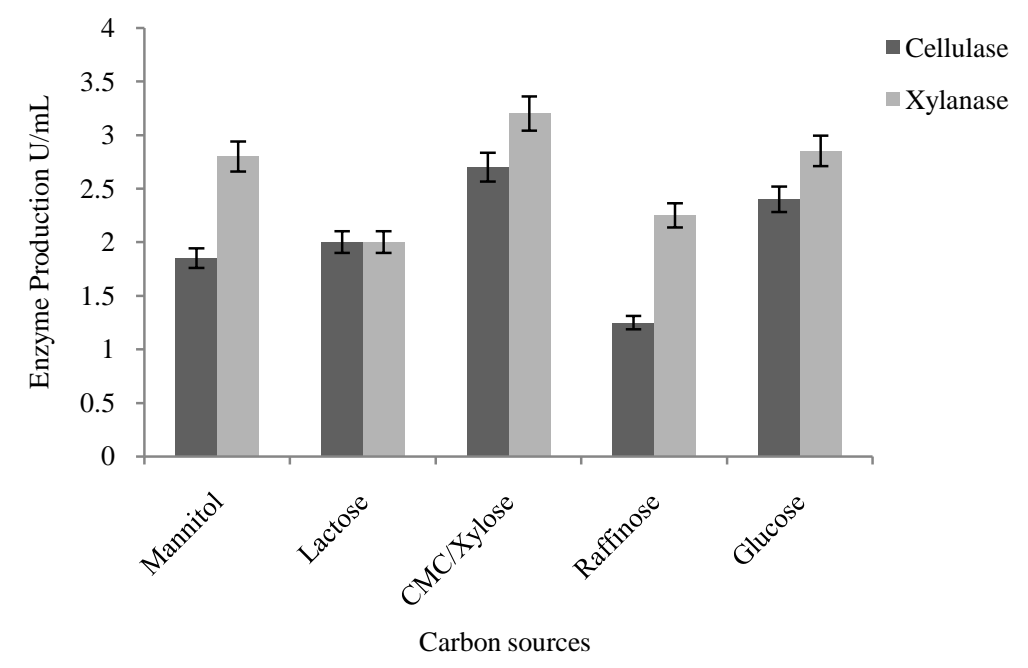

Figure 5. Effect of carbon sources on cellulase and xylanase production by Aspergillus terreus KJ829487. 
group are typically soil organisms, abundant in soil and decaying litter and a great variety of materials useful to man which includes grains, straw and forage products, cotton and other fibrous materials. [27] reported in their work on the optimization of cellulase production by A. terreus the ability of the organism to produce high concentration of cellulase enzymes. Also, [28] confirmed that Aspergillus sp. have the capability to produce large amounts of cellulolytic enzymes. Utilization of $\mathrm{pH}$ is considered as an important factor during enzyme production. According to [29], they have been able to establish that cellulase and xylanase experience of most filamentous fungi are $\mathrm{pH}$ dependent. [30] reported an optimum of $\mathrm{pH} 5$ and 8 for cellulase and xylanase during enzyme production of Trichoderma viride. The optimum temperature for growth of fungus may not necessarily be the optimum temperature for production of enzymes, although incubation temperature is a critical factor in enzyme production according to [31]. The result for the cellulase production at $40^{\circ} \mathrm{C}$ is in accordance with the work of [32], who also obtained a maximum temperature of $40^{\circ} \mathrm{C}$ for A. terreus AV49 using pretreated groundnut shell as substrate, this observation is similar to previous studies carried out by [33] and [27]. Optimal temperature for xylanase in this work is obtained at $40^{\circ} \mathrm{C}$ and this is not in agreement with the work of [31] who obtained an optimal temperature for xylanase activity at $28^{\circ} \mathrm{C}$ for A. niger, while [34] reported $35^{\circ} \mathrm{C}$ for A. terreus UL4206 and [35] reported optimum temperature for xylanase production by A. sulphurous cultivated from agro industrial wastes to be between $30^{\circ} \mathrm{C}$ and $45^{\circ} \mathrm{C}$. [36] also reported that organic nitrogen sources are more suitable for the optimal production of cellulase and xylanase. [37] establish the fact that addition of yeast extract always lead to an increase in cellulase and xylanase production by $A$. terreus which explains the high production of enzymes using yeast extract in this study. [38] and [39], reported that using CMC is the most favourable carbon source for screening cellulolytic fungi. Also, [40] supports the use of xylose as carbon source to improve xylanase production in filamentous fungi. Basic principle underlying acid pretreatment method is that the acid removes the hemicellulosic components of the peels thereby exposing the cellulose to enzymatic digestion [41]. At this point the cellulose is extremely susceptible to hydrolysis [42]. This shows that acid hydrolysis significantly $(\mathrm{P}<0.05)$ enhanced saccharification of cassava peels with the isolate enzyme. Pretreatment or hydrolysis with sulphuric acid has removed and hydrolysed hemicellulose to their monomeric constituent and lignin-hemicellulose cellulose interactions partially disrupted [43]. This pretreatment therefore solubilised the cellulose making it amenable to attack by the cellulase produced by the isolates. The acid disrupts the hydrogen bonding between cellulose chains, converting it to a completely amorphous state, thereby forming a homogenous gelatin with the acid. At this point the cellulose is extremely susceptible to hydrolysis [44]. [45] reported that dilute sulphuric acid hydrolysis is the best processing options for desirable characteristics like low cost of chemicals for pretreatment, minimal waste production, limited size reduction, fast reaction and production of high concentration of sugars.

\section{Conclusion}

Aspergillus terreus KJ829487 obtained from cassava peels have the ability to produce high concentrations of cellulases and xylanases which can be applied for effective bioconversion of cassava peels to fermentable sugars that can be further processed for manufacturing of value added products.

\section{References}

[1] Nartey, F. (1979) Studies on Cassava Cynogenesis, and Biosynthesis of Cynogenic Glucoside in Cassava (Manihot spp.), In: Nestel, B. and Maclntyre, R., Eds., Chronic Cassava Toxicity, IDRC 010e: 73-87.

[2] Picart, P. (2007) Cellulases from Two Penicillium sp. Strains Isolated from Subtropical Forest Soil: Production and Characterization. Letters of Applied Microbiology, 45, 108-113. http://dx.doi.org/10.1111/j.1472-765X.2007.02148.x

[3] Hayward, T.K. (1999) Enzyme Production, Growth, and Adaptation of T. reseei Strains QM9414, L27, RL-P37 and Rut C-30 in Conditioned Yellow Poplar Sawdust Hydrolysate. Applied Biochemistry Biotechnology, 77-79, $293-309$. http://dx.doi.org/10.1385/ABAB:77:1-3:293

[4] Jorgensen, H., Mørkeberg, A., Krogh, K.B.R. and Olsson, L. (2005) Production of Cellulases and Hemicellulases by Three Penicillium Species: Effect of Substrate and Evaluation of Cellulase Adsorption by Capillary Electrophoresis. Enzyme Microbiology Technology, 36, 42-48. http://dx.doi.org/10.1016/j.enzmictec.2004.03.023

[5] Shahriarinour, M., Abdulwahab, M.N., Mohamad, R., Mustafa, S. and Ariff, A.B. (2011) Effect of Medium Composition and Cultural Condition on Cellulase Production by Aspergillus terreus. African Journal of Biotechnology, 10, 7459-7467.

[6] Lockington, R.A., Rodbourn, L., Berneth, S.A., Carter, C.J. and Kelly, J.M. (2002) Regulation by Carbon and Nitrogen 
Sources of a Family of Cellulases in Aspergillus nidulans. Journal of Fungal General Biology, 37, 190-196. http://dx.doi.org/10.1016/S1087-1845(02)00504-2

[7] Ong, L.G.A., Abd-Aziz, S., Noraini, S., Karim, M.I.A. and Hassan, M.A. (2004) Enzyme Production and Profile by Aspergillus niger during Solid Substrate Fermentation Using Palm Kernel Cake as Substrate. Journal of Applied Biochemistry and Biotechnology, 18, 73-79. http://dx.doi.org/10.1385/ABAB:118:1-3:073

[8] Wang, X.J., Bai, J.G. and Liang, Y.X. (2006) Optimization of Multienzyme Production by Two Mixed Strains in Solid-State Fermentation. Applied Microbiology and Biotechnology, 73, 533-540. http://www.ncbi.nlm.nih.gov/pubmed/16802152 http://dx.doi.org/10.1007/s00253-006-0496-1

[9] Bhat, M.K. (2000) Cellulases and Related Enzymes in Biotechnology. Journal of Biotechnology Advances, 18, 355383. http://dx.doi.org/10.1016/S0734-9750(00)00041-0

[10] Fengel, D. and Wegener, G. (1989) Wood: Chemistry, Ultrastructure, Reactions. Walter de Gruyter, New York.

[11] Gupta, G., Sahai, V. and Gupta, R.K. (2013) Optimisation of Xylanase Production from Melanocarpus albomyces Using Wheat Straw Extract and Its Scale up in Stirred Tank Bioreactor. Indian Journal of Chemical Technology, 20, 282-289.

[12] Li, X., Li, E., Zhu, Y., Teng, C., Sun, B., Sang, H. and Yang, R. (2012) A Typical Endoxylanase from Streptomyces rameus L2001 and Its Unique Characteristics in Xylooligosaccharide Production. Journal of Carbohydrate Resources, 359, 30. http://dx.doi.org/10.1016/j.carres.2012.05.005

[13] Wong, K.K., Tan, L.U. and Saddler, J.N. (1988) Multiplicity of Beta-1,4-Xylanase in Microorganisms: Functions and Applications. Journal of Microbiology Review, 52, 305-317.

[14] Haltrich, D., Nidetzky, B., Kulbe, K.D., Steiner, W. and Zupancic, S. (1996) Production of Fungal Xylanases. Bioresource Technology, 58, 137-161. http://dx.doi.org/10.1016/S0960-8524(96)00094-6

[15] Davin, L.B. and Lewis, N.G. (2005) Lignin Primary Structures and Dirigent Sites. Journal of Current Opinion in Biotechnology, 16, 407-415. http://dx.doi.org/10.1016/j.copbio.2005.06.011

[16] Chandra, R., Raj, A., Purohit, H.J. and Kapley, A. (2007) Characterization and Optimization of Three Potential Aerobic Bacterial Strains for Kraft Lignin Degradation from Pulp Paper Waste. Chemosphere, 67, 839-846. http://dx.doi.org/10.1016/j.chemosphere.2006.10.011

[17] James, G.C. and Natalie, S. (2001) Microbiology: A Laboratory Manual. 3rd Edition, Benjamin/Cummings Publishing Company, Redwood City, 211-223.

[18] Gams, W., Domsch, K.H. and Anderson, T.H. (1980) Compedium of Soil Fungi. Vol. 1, Academic Press, London.

[19] Kanlaya, Y. and Jirasak, K. (2004) A Study of Optimal Conditions for Reducing Sugars Production from Cassava Peels by Diluted Acid and Enzymes. Natural Science, 38, 29-35.

[20] Miller, G.L. (1959) Use of Dinitrosalicylic Acid Reagent for Determination of Reducing Sugar. Analytical Chemistry, 31, 426-428. http://dx.doi.org/10.1021/ac60147a030

[21] Binder and Hibbett (2003) Hibbett Lab Protocols for DNA Isolation, PCR, and DNA Sequencing.

[22] Vahidi, H., Kobarfard, F. and Nanyoyan, F. (2004) Effect of Cultivation Conditions on Growth and Antifungal Activity of Mycena leptocephala. African Journal of Biotechnology, 3, 606-609. http://www.academicjournals.org/AJB/PDF/Pdf2004/Nov/Vahidi\%20et\%20al.pdf

[23] Rajoka, M.I. and Malik, K.A. (1997) Cellulase Production by Cellulomonas biazotea Cultured in Media Containing Different Cellulosic Substrates. Bioresource Technology, 59, 21-27. http://dx.doi.org/10.1016/S0960-8524(96)00136-8

[24] Laurence, D.M. and Bronwen, G.S. (2001) Current Protocols in Food Analytical Chemistry E3.2.1-E3.2.13. John Wiley \& Sons Inc., Hoboken.

[25] Gawande, P.V. and Kamat, M.Y. (2000) Production of Xylanases by Immobilized Aspergillus sp. Using Lignocellulosic Waste. World Journal of Microbiology Biotechnology, 16, 111-112. http://dx.doi.org/10.1023/A:1008969615866

[26] Gupta, R. and Mukerji, K.G. (2001) Fungi as a Major Group of Organisms. Microbial Technology, A.P.H. Publishing Corporation, New Delhi, 1-6.

[27] Lin, H., Cheng, W., Ding, H.T., Chen, X.J., Zhou, Q.F. and Zhao, Y.H. (2010) Direct Microbial Conversion of Wheat Straw into Lipid by a Cellulolytic Fungus of Aspergillus oryzae A-4 in Solid-State Fermentation. Bioresource Technology, 101, 7556-7562.

[28] Dashtban, M., Heidi, S. and Wensheng, Q. (2009) Fungal Bioconversion of Lignocellulosic Residues: Opportunities \& Perspectives. International Journal of Biological Sciences, 5, 578-595. http://www.biolsci.org

[29] Silva, R.C., Cotting, L.N., Poltronien, T.P., Balcao, V.M., De Almeida, D.B.G., Goncalves, L.A., Grimaldi, R. and Gioelli, L.A. (2009) The Effects of Enzymatic Interesterification on the Physical Chemical Properties of Blends of 
Lard and Soybean Oil. LWT_Food Science and Technology, 42, 1275-1282.

[30] Maria, L.G.S., Samia, M.T.T. and Daniel, M.T.T. (2009) Screening of Culture Condition for Xylanase Production by Filamentous Fungi. African Journal of Biotechnology, 8, 6317-6326.

[31] Kheng, P.P. and Omar, I.C. (2005) Xylanase Production by a Local Fungal Isolate, Aspergillus niger USM AI 1 via Solid State Fermentation Using Palm Kernel Cake (PKC) as Substrate. Songklanakarin Journal of Science and Technology, 27, 325-336.

[32] Vyas, A., Vyas, D. and Vyas, K.M. (2005) Production and Optimization of Cellulases on Pretreated Groundnut Shell by Aspergillus terreus AV49. Journal of Scientific and Industrial Research, 64, 281-286.

[33] Sherief, A.A., El-Tanash, A.B. and Atia, N. (2010) Cellulase Production of Aspergillus fumigatus Grown on Mixed Substrate of Rice Straw and Wheat Bran. Research Journal of Microbiology, 5, 199-211.

[34] Chidi, S.B., Godana, B., Naibe, I., Rensburg, E.J.V., Cronshaw, A. and Abotsi, E.K. (2008) Production, Purification and Characterization of Cellulase-Free Xylanase from Aspergillus terreus UL4209. African Journal of Biotechnology, 7, 3939-3948.

[35] Lu, W., Li, D. and Wu, Y. (2003) Influence of Water Activity and Temperature on Xylanase Biosynthesis in PilotScale Solid-State Fermentation by Aspergillus sulphureus. Enzyme and Microbial Technology, 32, 305-311. http://dx.doi.org/10.1016/S0141-0229(02)00292-2

[36] Ray, A.K., Bairagi, A., Ghosh, K.S. and Sen, S.K. (2007) Optimization of Fermentation Conditions for Cellulase Production by Bacillus subtilis CY5 and Bacillus circulans TP3 Isolated from Fish Gut. Acta Ichthyologica et Piscatoria, 37, 47-53. http://dx.doi.org/10.3750/AIP2007.37.1.07

[37] Ghanem, N.B., Yusef, H.H. and Mshrouse, H.K. (2000) Production of Aspergillus terreus Xylanase in Solid State Cultures: Application of the Plackett-Burman Experimental Design to Evaluate Nutritional Requirements. Bioresource Technology, 73, 113-121. http://dx.doi.org/10.1016/S0960-8524(99)00155-8

[38] Narasimha, G., Sridevi, A., Viswanath, B., Chandra, S.M. and Reddy, R.B. (2006) Nutrient Effects on Production of Cellulolytic Enzymes by Aspergillus niger. African Journal of Biotechnology, 5, 472-476. http://www.academicjournals.org/AJB

[39] Shahriarinour, M., Abd Wahab, M.N., Ariff, A. and Mohamad, R. (2011) Screening, Isolation and Selection of Cellulolytic Fungi from Oil Palm Empty Fruit Bunch Fibre. Biotechnology, 10, 108-113. http://dx.doi.org/10.3923/biotech.2011.108.113

[40] Garapati, S.L., Chaganti, S.R., Ravella, S.R., Phil, J.H. and Reddy, S.P. (2009) Enhanced Production of Xylanase by a Newly Isolated Aspergillus terreus under Solid State Fermentation Using Palm Industrial Waste: A Statistical Optimization. Journal of Science, 8, 41-47.

[41] Bandouna, L. (2011) Pseudomonas and Beyond: Polyamine Metabolism, Lignin Degradation and Potential Applications in Industrial Biotechnology. Master of Science in Molecular Cell Biology and Bioinformatics, Geboren te Vanderbijlpark, South Africa.

[42] Hsu, T.A., Ladisch, M.R. and Tsao, G.T. (1980) Alcohol from Cellulose. Chemical Technology, 10, 315-319.

[43] Ladisch, M.R., Lin, K.W., Voloch, M. and Tsao, G.T. (1983) Process Considerations in Enzymatic Hydrolysis of Biomass. Enzyme and Microbial Technology, 5, 82-102. http://dx.doi.org/10.1016/0141-0229(83)90042-X

[44] Hsu, T.A. (1996) Pretreatment of Biomass. In: Wyman, C.E., Ed., Handbook on Biomass Ethanol, Taylor and Francis, Washington DC, 179-212. http://www.purdue.edu/lorre/publications/mayp315-319y1980.pdf

[45] Ehsan, D., Vahid, Z., Rouhollah, R. and Najaf, H. (2012) Kinetic Analysis of Sugarcane Bagasse Hydrolysis Process. Dezful Branch, Islamic Azad University, Dezful. 


\section{Submit or recommend next manuscript to SCIRP and we will provide best service for you:}

Accepting pre-submission inquiries through Email, Facebook, Linkedin, Twitter, etc A wide selection of journals (inclusive of 9 subjects, more than 200 journals)

Providing a 24-hour high-quality service

User-friendly online submission system

Fair and swift peer-review system

Efficient typesetting and proofreading procedure

Display of the result of downloads and visits, as well as the number of cited articles

Maximum dissemination of your research work

Submit your manuscript at: http://papersubmission.scirp.org/ 